\title{
An Early Neoproterozoic Accretionary Prism Ophiolitic Mélange from the Western Jiangnan Orogenic Belt, South China
}

\author{
Jinlong Yao, ${ }^{1}$ Peter A. Cawood, ${ }^{2}$ Liangshu Shu, ${ }^{1, \star}$ M. Santosh, ${ }^{3}$ and Jinyi $\mathrm{Li}^{4}$ \\ 1. State Key Laboratory for Mineral Deposits Research, School of Earth Sciences and Engineering, Nanjing \\ University, Nanjing 210093, China; 2. Department of Earth Sciences, University of St. Andrews, North \\ Street, St. Andrews KY16 9AL, United Kingdom; and School of Earth and Environment, University of \\ Western Australia, 35 Stirling Highway, Crawley, Western Australia 6009, Australia; 3. School of \\ Earth Sciences and Resources, China University of Geosciences, Beijing, No. 29 Xueyuan Road, \\ Haidian District, Beijing 100083, China; 4. Institute of Geology, Chinese Academy \\ of Geological Sciences, Beijing 100037, China
}

\begin{abstract}
A B S T R A C T
The Neoproterozoic Jiangnan orogenic belt delineates the suture zone between the Cathaysia and Yangtze blocks of the South China Craton. The western part of the belt, in the Longsheng region, consists of a disrupted mafic-ultramafic assemblage of pillow basalt, gabbro, diabase, and peridotite along with siliceous marble, ophicalcite, and jasper mixed with basalt. Significant talc deposits occur on the margins of the ultramafic bodies as well as in the transition zone between marble and basalt. Primary rock relations are largely overprinted by pervasive shearing, resulting in disruption of the assemblage into series of discontinuous blocks within a phyllite matrix. West-dipping thrust faults mark the eastern contact of blocks, and the overall succession has the appearance of a tectonic mélange. U-Pb zircon age data from the gabbros and diabases yield crystallization ages of $867 \pm 10,863 \pm 8$, and $869 \pm 9 \mathrm{Ma}$, with positive $\varepsilon \mathrm{Hf}(t)$ values. The gabbro, basalt, serpentinite, and some talc samples display minor light rare earth element-enriched patterns with obvious depletion of $\mathrm{Nb}$ and $\mathrm{Ta}$, indicating a subduction-related setting. The tuffaceous phyllite shows similar geochemical features. A few mafic rocks and the altered ultramafic rocks display mid-ocean ridge basalt (MORB) affinity. Overall lithostratigraphic relationships, age data, and geochemical signatures suggest a forearc setting that was imbricated and disrupted within an accretionary prism environment to form an ophiolitic mélange. The pillow basalt, red jasper, and MORB-type mafic-ultramafic rocks within the mélange occur as exotic blocks derived from the subducting oceanic plate, whereas the arc-type mafic rocks occur as autochthonous blocks, which are all exposed in a matrix of sandy and tuffaceous phyllite.
\end{abstract}

Online enhancements: supplemental tables.

\section{Introduction}

Ophiolites are generally formed in two tectonic settings: suprasubduction zones (SSZ type) and midocean ridge spreading centers (MORB type), with subsequent preservation in the rock record dependent on a variety of emplacement mechanisms (Pearce 2003; Wakabayashi and Dilek 2003; Stern et al. 2012). The majority of ophiolites are emplaced at convergent plate margins, including protoarc, forearc, and back-

Manuscript received October 17, 2015; accepted May 2, 2016; electronically published August 16, 2016.

* Author for correspondence; e-mail: 1sshu@nju.edu.cn. arc settings. The recognition of ophiolites in the rock record, often on the basis of integrated lithotectonic and geochemical data, can provide important constraints on tectonic evolution and paleogeography. Ophiolitic mélange is a mixture of sedimentary rocks and igneous rocks of different origins set in a matrix of either shale-sandstone or serpentinite, with some igneous components derived from the ophiolite suite. Exotic blocks of unknown provenances are common within ophiolitic mélange. The formation of ophiolitic mélange generally occurs at convergent plate boundaries involving either obduction (Gansser 1974) or subduction (Williams 1977). In this article,

[The Journal of Geology, 2016, volume 124, p. 587-601] (c) 2016 by The University of Chicago. All rights reserved. 0022-1376/2016/12405-0003\$15.00. DOI: 10.1086/687396 
we document an ophiolitic mélange from the western Jiangnan belt in South China and argue for its emplacement at a Neoproterozoic convergent plate margin.

The South China Craton is composed of the Yangtze block to the northwest and the Cathaysia block to the southeast (fig. 1). In the Neoproterozoic, these two tectonic units were assembled along the ENEWSW-trending Jiangnan orogenic belt (also called the Sibao or Jinning orogenic belt; fig. 1), which can be traced some $1500 \mathrm{~km}$ along strike and extends up to $120 \mathrm{~km}$ across strike (Shu 2012). Neoproterozoic arc and trench successions within and adjoining the boundary zone were assembled in an accretionary orogenic belt (fig. 1; Cawood et al. 2013). However, the timing of formation of the trench-arc sequences and the number and direction of subduction zones involved in the assembly of the two blocks, as well as the age and emplacement mechanism of ophiolite suites or ophiolitic mélanges, are poorly constrained (Shu 2012; Cawood et al. 2013; Wang et al. 2015; Zhao 2015). Furthermore, the broader role and po- sition of South China in the assembly of the Rodinia supercontinent remains speculative (e.g., Li et al. 2008; Cawood et al. 2013; Wang et al. 2013).

The southwestern part of the Jiangnan belt in northern Guangxi is the focus of this article (fig. 1). Our study outlines field, geochemical, and isotopic data on mafic-ultramafic and associated sedimentary units around some of China's largest talc mines at Longsheng, northern Guangxi province (fig. 2).

\section{Geological Setting and Sample Descriptions}

Geological Setting. The Yangtze block is composed of an Archean-Paleoproterozoic crystalline basement surrounded by Neoproterozoic orogenic belts (Zhao and Cawood 2012; Wang et al. 2013). The Cathaysia block is composed predominantly of a Neoproterozoic-early Paleozoic assemblage of variably metamorphosed sedimentary and igneous rocks along with minor Paleoproterozoic igneous rocks (Shu 2012). In the early to middle Neoproterozoic, the Cathaysia and Yangtze blocks were accreted along

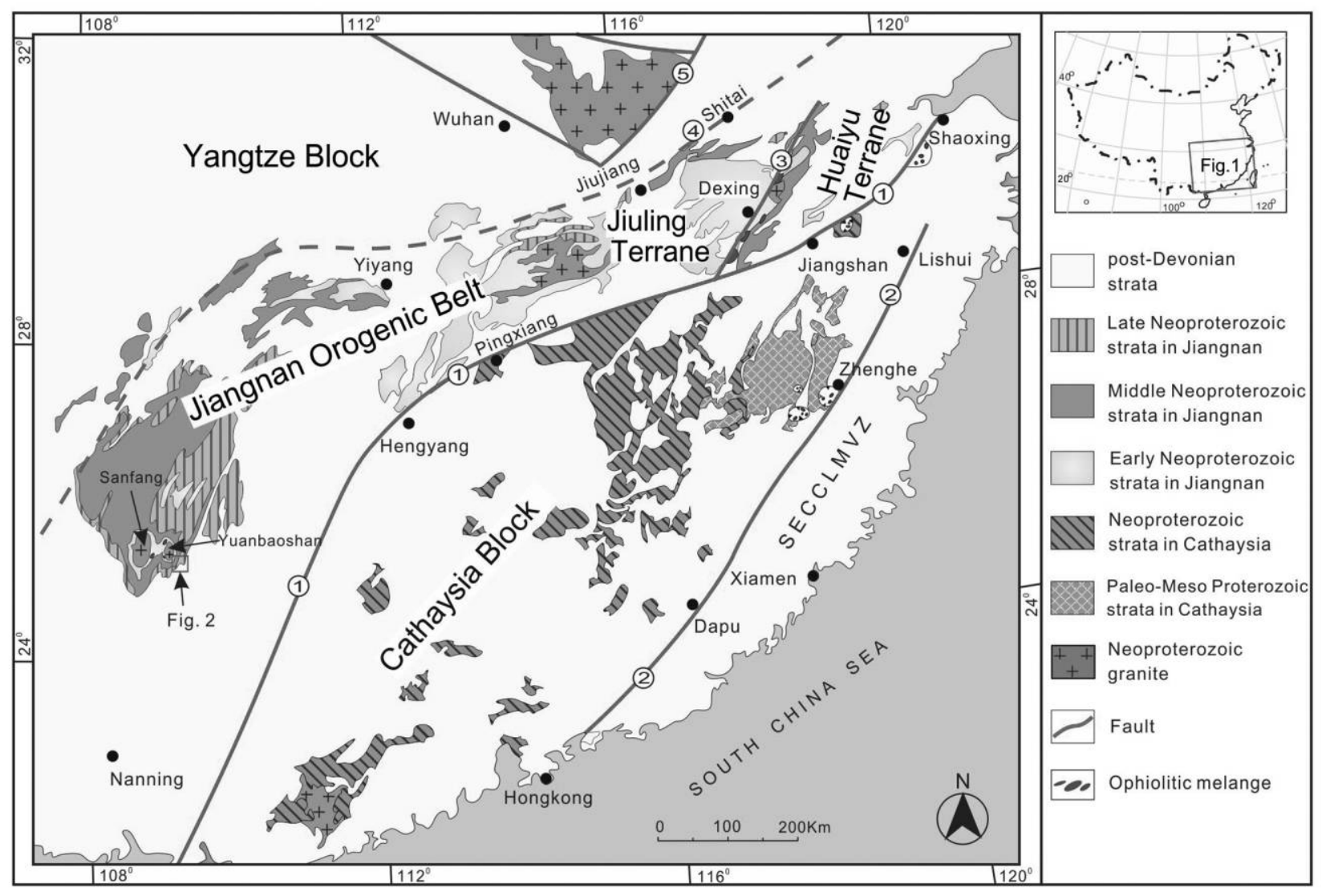

Figure 1. Geological sketch map of the Jiangnan orogenic belt, South China Craton. 1 = Shaoxing-JiangshanPingxiang-Shuangpai fault; 2 = Zhenghe-Dapu fault; 3 = Northeast Jiangxi fault; 4 = Jiujiang-Shitai fault; $5=$ Tanlu fault; SECCLMVZ = Southeast China costal late Mesozoic volcanic zone. A color version of this figure is available online. 


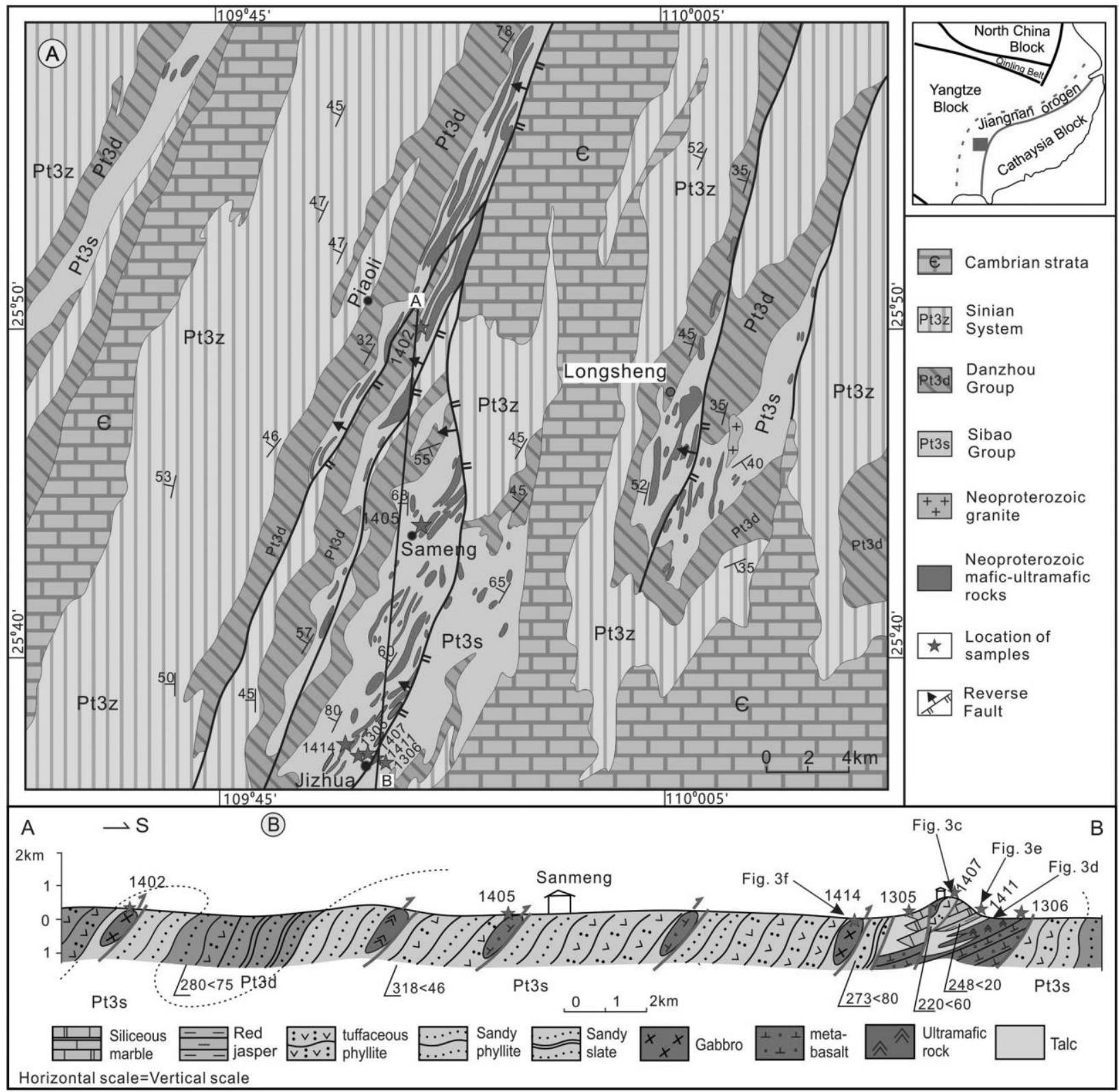

Figure 2. A, Geological sketch map of the Longsheng area in the western Jiangnan orogenic belt, South China. $\varepsilon=$ Cambrian strata; Pt3d = middle Neoproterozoic Danzhou Group; Pt3s = early Neoproterozoic Sibao Group; Pt3z = late Neoproterozoic Sinian system. B, Schematic cross section with sample locations. A color version of this figure is available online.

the Jiangnan orogenic belt to form the unified South China Craton (Shu 2012; Cawood et al. 2013; Wang et al. 2013), with exposures of Neoproterozoic ophiolite in the east Jiangnan belt (Shu et al. 1994; Li et al. 1997; Shu 2012) and along the northwestern margin of the Yangtze block (Sun and Vuagnat 1992).

At the Longsheng talc mines, the principal rock unit within the Jiangnan orogenic belt is the metamorphosed Neoproterozoic volcano-sedimentary Si- bao Group. Based on the ages of the youngest detrital zircon grains from a number of samples, the maximum depositional age of the group ranges from ca. 871 to $835 \mathrm{Ma}$ (Zhou et al. 2014). This unit is unconformably overlain by posttectonic, middle Neoproterozoic-early Paleozoic strata, the oldest unit of which is the Danzhou Group of the Nanhua system (BGMRGX 1985; Zhao and Cawood 2012 and references therein). The youngest detrital zircons 
from Danzhou Group samples range from ca. 819 to $731 \mathrm{Ma}$ (Zhou et al. 2014), suggesting that the group as a whole accumulated sometime after $730 \mathrm{Ma}$.

Mafic-ultramafic rocks occur throughout the Longsheng region, predominantly within thrust-bounded regional anticlines (fig. 2a). Talc, a product of alteration of the mafic-ultramafic rocks or metasomatism between carbonate and basalt, is exposed in the mines of the region (fig. 3a). To the northwest of
Longsheng, at Yuanbaoshan and Sanfang, gabbro intruding into or occurring as lenses within the Sibao Group has been dated at ca. 855 (zircon U-Pb; Yao et al. 2014) and 825 (zircon U-Pb; Li et al. 1999; Ge et al. 2001) Ma. Zhou et al. (2004) and Yao et al. (2014) proposed a subduction-related setting for these mafic-ultramafic suites, whereas Li et al. (1999) and Ge et al. (2001) suggested a plume setting related to the breakup of Rodinia.
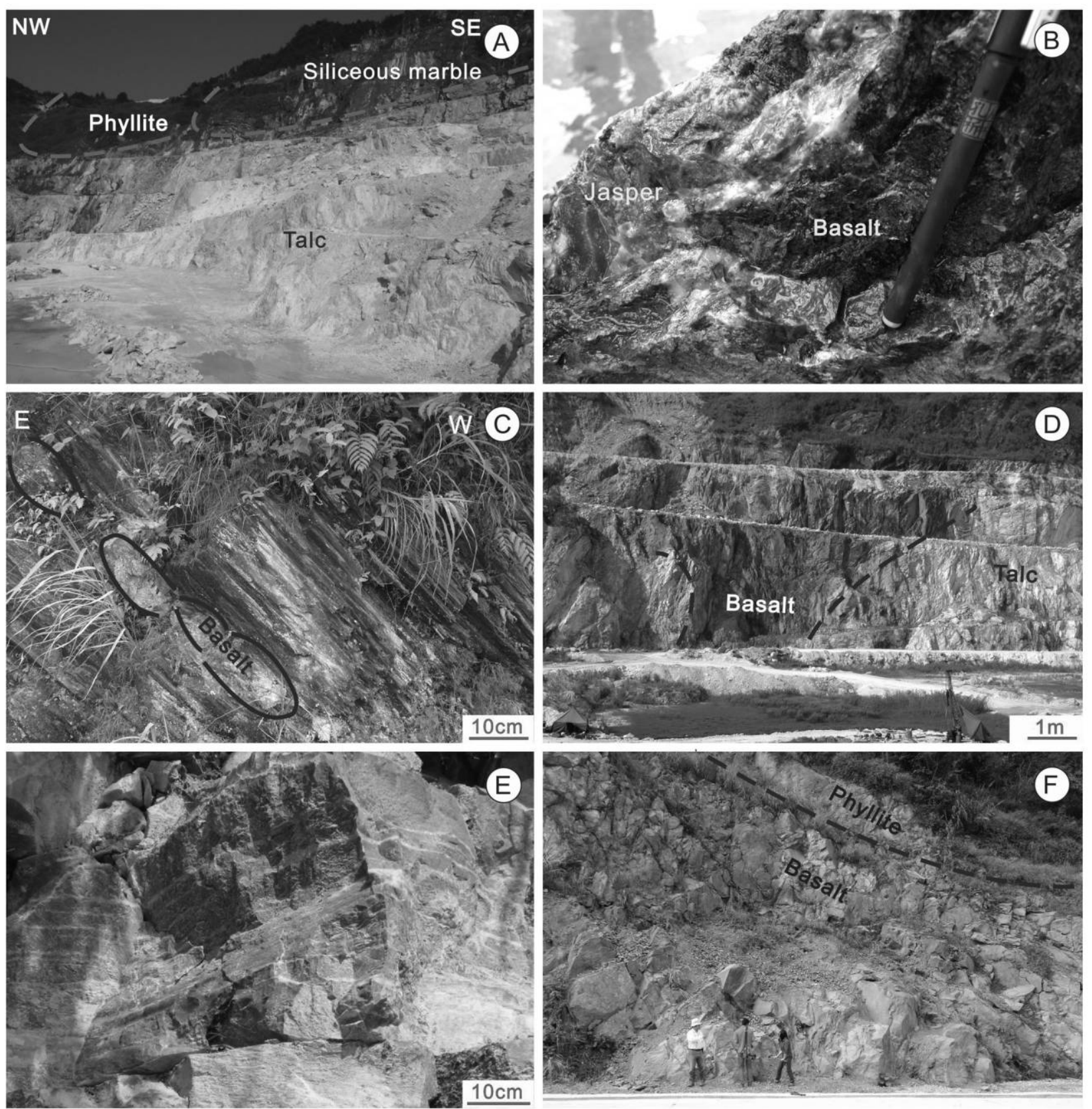

Figure 3. Representative field photos of samples analyzed in this study. $A$, Tectonic blocks in the talc mine. $B$, Red jasper mixed with basalt. $C$, Isolated basalt blocks within enclosing phyllite in the talc mine. $D$, Basalt in the talc. E, Ophicalcite. F, Basalt and overlying phyllite. A color version of this figure is available online. 
S-type peraluminous granitic plutons occur throughout the northern Guangxi area and locally intrude the mafic-ultramafic suite in the western Yuanbaoshan (Yao et al. 2014). The granites are sheared and yield ages ranging from ca. 830 to $800 \mathrm{Ma}$ (Yao et al. 2014). They have been interpreted as either collision related (Yao et al. 2014) or having formed in a rift setting related to a mantle plume (Li et al. 2003).

Lithostratigraphic Relationships and Occurrence of Mafic-Ultramafic Rocks and Related Rock Suites at Longsheng. The Sibao Group constitutes the oldest exposed rock unit in the Longsheng area (fig. 2a, 2b). It consists of pelite, chert, volcaniclastic rock, maficultramafic suites, and siliceous marble (figs. 2b, 3). Intermediate volcanic rocks and minor granodiorite have also been reported (BGMRGX 1985). Although lithostratigraphic principles have been applied to the unit, the stratigraphic sequence is pervasively sheared and consists of isolated blocks of basalt, marble, phyllite, and ophicalcite enveloped by phyllite and bounded by faults (figs. 2b, 3a). Maficultramafic bodies, which are generally serpentinized, are up to $200 \mathrm{~m}$ thick and can be traced for up to $5 \mathrm{~km}$. They are discontinuous both along strike and at depth (on the basis of drillhole data; Xia 1984; BGMRGX 1985). To the north of the talc mines, the eastern contact of the west-dipping mafic and ultramafic units and the chert and marble are delineated by east-directed thrust faults, suggesting that the succession is structurally imbricated (fig. $2 a$; Xia 1984; BGMRGX 1985). The unit is metamorphosed to greenschist to amphibolite facies, with tremoliteactinolite, talc, chlorite, and serpentine being common metamorphic minerals in the ultramafic rocks, whereas tremolite-actinolite, albite, zoisite, and chlorite are metamorphic minerals in mafic rocks. The metamorphic minerals display an oriented texture, indicating that their growth was syndeformational.

Talc is developed within ultramafic rocks or at contact zones between the mafic-ultramafic units and adjoining lithologies (fig. 2b; Li 1979). Primary stratigraphic relations are preserved in some tectonic blocks, with siliceous marble overlying basalt and with jasper (chert) overlying and intermingled with basalt (fig. $3 b$ ). Pillowed and amygdaloidal basalts are well developed in the mafic lithologies. Previous age data for the region include single-grain zircon $\mathrm{U}-\mathrm{Pb}$ ages of ca. $837 \mathrm{Ma}$ for lenticular mafic rocks, but method and errors were not given (BGMRGX 1985). Zhou et al. (2007) obtained a laser ablation inductively coupled plasma mass spectrometry (LA-ICP-MS) zircon U-Pb age of $765 \pm$ $14 \mathrm{Ma}$ from a late intrusive metadacite.
The overlying Danzhou Group contains a series of conglomerate, sandstone, siltstone, and mudstone approximately $3500 \mathrm{~m}$ thick. The group is part of the Nanhua system and constitutes a rift succession of nonmarine to paralic clastic facies (Chen et al. 1997; Wang and Li 2003) and regionally contains bimodal volcanic rocks (Shu 2012). Rock units of the Nanhua system extend across the Jiangnan belt and Cathaysia block and provide the first strata linkage between the two. Further strata linkages occur in the Devonian (Chen et al. 1997).

Sample Descriptions. In this study, we selected for analysis two foliated gabbro samples (1402 and 1402-1; GPS: $\left.25^{\circ} 45.919^{\prime} \mathrm{N}, 109^{\circ} 50.071^{\prime} \mathrm{E}\right)$ and four gabbro samples (1405, 1405-1, 1405-2, and 1405-3; GPS: $25^{\circ}$ $40.259^{\prime} \mathrm{N}, 109^{\circ} 50.258^{\prime} \mathrm{E}$ ) from near the town of Sanmeng (fig. 2). Four gabbro and massive coarse-grained samples (1414, 1414-1, 1414-2, and 1414-3; GPS: $25^{\circ}$ $36.762^{\prime} \mathrm{N}, 109^{\circ} 49.238^{\prime} \mathrm{E}$ ) were also collected from the northern margin of the talc mine (fig. $2 b$ ). In addition, one jasper $\left(1411\right.$; GPS: $25^{\circ} 35.552^{\prime} \mathrm{N}, 109^{\circ} 48$. $890^{\prime} \mathrm{E}$ ), two serpentinite (1306-2 and 1306-2-1; GPS: $25^{\circ} 23.681^{\prime} \mathrm{N}, 109^{\circ} 06.208^{\prime} \mathrm{E}$ ), four talc (1305 and 1305-1, northern talc mine; 1306-1 and 1306-1-1, southern talc mine; GPS: $25^{\circ} 35.714^{\prime} \mathrm{N}, 109^{\circ} 49.121^{\prime} \mathrm{E}$ ), and two phyllite (1407 and 1409; GPS: $25^{\circ} 35.993^{\prime} \mathrm{N}, 1^{\circ} 9^{\circ} 49.485^{\prime} \mathrm{E}$ ) samples were collected from the Longsheng talc mines (fig. 2b).

The gabbro samples 1402, 1402-1, 1405, and 1405-2 contain about $50 \%$ plagioclase, $30 \%$ augite, and $5 \%$ opaque oxide phases (fig. 4) along with some 15\% chlorite, uralite, and calcite veins (the latter phases after pyroxene). Gabbro sample 1414 contains $40 \%-$ $60 \%$ plagioclase, $8 \%$ olivine, $22 \%$ augite, $5 \%$ diopside, $5 \%$ actinolite, $5 \%$ chlorite, and $5 \%$ opaque oxide phase. The serpentinite samples (1306-2 and 1306-2-1) are composed of $75 \%$ serpentine, $15 \%$ pyroxene, $5 \%$ amphibole, and $5 \%$ accessory minerals. The talc samples (1305, 1305-1, 1306-1, and 1306-1-1) are composed mainly of talc and a minor amount of antigorite (fig. 4). The ophicalcite sample (1306-5) contains $85 \%$ calcite and $15 \%$ quartz veins. The phyllite samples (1407 and 1409) are composed mainly of quartz, feldspar, muscovite, and chlorite (fig. 4). Gabbro and diabase samples 1402, 1405, and 1414 were selected for zircon $\mathrm{U}-\mathrm{Pb}$ dating and $\mathrm{Hf}$ isotope analysis, and the rest were analyzed for whole-rock geochemistry.

\section{Analytical Procedures}

Zircons were separated from the crushed rocks using heavy liquid and magnetic techniques and then handpicked under a binocular microscope. The zircon grains were mounted in epoxy resin, polished, 

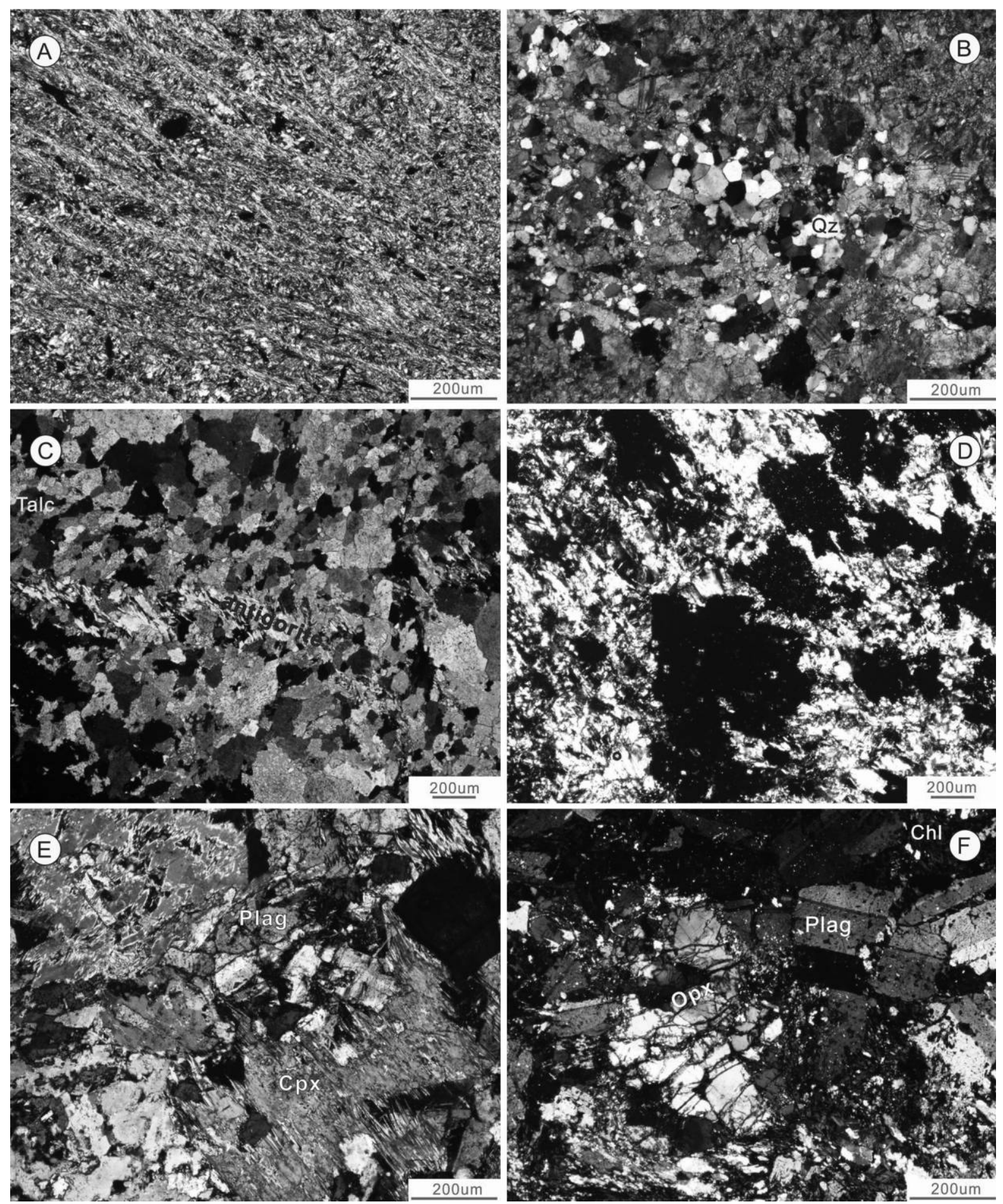

Figure 4. Thin-section photomicrographs of samples analyzed in this study. A, Phyllite sample 1407 (crossed nicols). $B$, Ophicalcite sample 1411 (crossed nicols). C, Talc sample 1305 (crossed nicols). D, Serpentinite sample 1407 (crossed nicols). E, Gabbro sample 1405 (crossed nicols). F, Gabbro sample 1414 (crossed nicols). Chl = cholerite; $\mathrm{Cpx}=$ clinopyroxene; Mus = muscovite; $\mathrm{Ol}=$ olivine; Plag = plagioclase; $\mathrm{Qz}=$ quartz. A color version of this figure is available online. 
and coated. Cathodoluminescence $(\mathrm{CL})$ images of the zircons were obtained using a Quanta 400 FEG electron microscope equipped with Mono CL3+ (Gatan) at the State Key Laboratory of Continental Dynamics at Northwest University.

Zircon $\mathrm{U}-\mathrm{Pb}$ isotopic dating was carried out at the State Key Laboratory for Mineral Deposits Research at Nanjing University using an Agilent 7500a ICPMS connected to a New Wave 213-nm laser ablation system. U-Pb fractionation was corrected using zircon standard GEMOC GJ-1 with a ${ }^{207} \mathrm{~Pb} / 206 \mathrm{~Pb}$ age of $601 \pm 12 \mathrm{Ma}$, and accuracy was monitored by using the zircon standard Mud Tank with an age of $735 \pm 12 \mathrm{Ma}$. The U-Pb ages were calculated from the original signal data using the software Glitter, and $\mathrm{U}-\mathrm{Th}-\mathrm{Pb}$ age data were plotted on concordia diagrams using the Isoplot program (Ludwig 2003). Zircons older than $1000 \mathrm{Ma}$ have high contents of radiogenic $\mathrm{Pb}$; hence, the ${ }^{207} \mathrm{~Pb} /{ }^{206} \mathrm{~Pb}$ age is more reliable and is used to determine the crystallization age. On the other hand, due to low content of radiogenic $\mathrm{Pb}$, the ${ }^{206} \mathrm{~Pb} /{ }^{238} \mathrm{U}$ age is more reliable for zircons with ages younger than $1000 \mathrm{Ma}$.

Zircon Hf isotopes were analyzed using a Neptune multicollector ICP-MS at the State Key Laboratory for Mineral Deposits Research at Nanjing University. Standard zircon 91500 was used for external correction, with a ${ }^{176} \mathrm{Hf} /{ }^{177} \mathrm{Hf}$ value of $0.282300 \pm 8(2 \sigma)$. Initial ${ }^{176} \mathrm{Hf} /{ }^{177} \mathrm{Hf}$ values were calculated on the basis of a Lu decay constant of $1.865 \times 10^{-11}$ (Scherer et al. 2001). The Hf model ages were calculated under the assumption that the ${ }^{176} \mathrm{Lu} /{ }^{177} \mathrm{Hf}$ value of the average crust is 0.015 ; the ${ }^{176} \mathrm{Hf} /{ }^{177} \mathrm{Hf}$ and ${ }^{176} \mathrm{Lu} /{ }^{177} \mathrm{Hf}$ ratios of chondrite at the present time are 0.282772 and 0.0332 , respectively; and the ${ }^{176} \mathrm{Hf} /{ }^{177} \mathrm{Hf}$ and ${ }^{176} \mathrm{Lu} /{ }^{177} \mathrm{Hf}$ ratios of depleted mantle at the present time are 0.28325 and 0.0384, respectively (Blichert-Toft and Albarede 1997).

Whole-rock major element analysis was performed using an ARL9800XP + X-ray fluorescence spectrometer at the State Key Laboratory for Mineral Deposits Research at Nanjing University. The analytical precision is generally better than $2 \%$ for all elements. Trace element abundances were measured using a Finnigan Element II ICP-MS at the State Key Laboratory for Mineral Deposits Research at Nanjing University, which gives precision better than $10 \%$ for most of the analyzed elements.

\section{Analytical Results}

Zircon U-Pb Dating. Zircons obtained from gabbro and diabase samples 1402, 1405, and 1414 are euhedral prismatic grains or fragments of euhedral grains. Most of the grains show banded zoning in CL images (fig. 5), typical of grains crystallized from magmas. Core and rim structures indicative of multiple growth episodes were noted in a few zircon grains (fig. 5).

Among 22 analyses from sample 1402, 14 concordant analyses yield an age range of $886-853 \mathrm{Ma}$, with a weighted-average ${ }^{206} \mathrm{~Pb} /{ }^{238} \mathrm{U}$ age of $867 \pm$ $10 \mathrm{Ma}$ (MSWD $=0.25$; fig. 5). Twenty-six analyses were conducted on zircons from sample 1405, with 10 grains yielding an age range of $871-857 \mathrm{Ma}$ and a weighted-average ${ }^{206} \mathrm{~Pb} /{ }^{238} \mathrm{U}$ age of $867 \pm 10 \mathrm{Ma}$ $($ MSWD $=0.102)$. Nineteen grains from sample 1414 were analyzed, yielding a main age range of 996-861 Ma with nine concordant analyses giving a weighted-average ${ }^{206} \mathrm{~Pb} /{ }^{238} \mathrm{U}$ age of $869 \pm 9 \mathrm{Ma}$ (MSWD $=0.08$; fig. 5 ). The $\mathrm{Th} / \mathrm{U}$ ratios of zircons from sample 1402 range from 0.5 to 3.0, whereas those from samples 1405 and 1414 range from 0.4 to 2.62 and 0.1 to 1.98 , respectively (table S1; tables S1S3 are available online). These weighted mean ages are interpreted as the crystallization age of the gabbro and diabase samples.

Six analyses from sample 1402 also yield Paleoproterozoic ages (2473-2262 Ma). Core and rim structures indicative of multiple growth episodes were noticed in these zircon grains (fig. 5). Zircons with similar core and rim structures were also found in samples 1405 and 1414, which yield ages of 28591043 and 2726-1003 Ma, respectively. These zircons yield variable $\mathrm{Th} / \mathrm{U}$ ratios and are most likely xenocrysts captured by the mafic magma.

Zircon Hf Isotopes. Zircons from samples 1402, 1405 , and 1414 with age ranges of $860-880$ Ma display mostly present-day ${ }^{176} \mathrm{Hf} /{ }^{177} \mathrm{Hf}$ ratios of $0.282401-$ 0.282618 and yield positive $\varepsilon \mathrm{Hf}(t)$ values of 0.04 $9.64,1.89-7.21$, and 1.61-8.52, respectively (table S2). This equates to Hf model ages of 1.25-1.0 Ga (fig. 6), suggesting the presence of latest Mesoproterozoic juvenile mantle material in this region.

Older inherited grains within the three samples display a range of $\varepsilon \mathrm{Hf}(t)$ values: five early Paleoproterozoic (ca. 2262-2473 Ma) grains from sample 1402 have $\varepsilon \mathrm{Hf}(t)$ values of 4.82 to $-12.87,957-2859 \mathrm{Ma}$ zircons in sample 1405 show $\varepsilon \mathrm{Hf}(t)$ values of 15.35 to -16.15 , and 15 zircons with ages in the range of 925-2726 Ma from sample 1414 display $\varepsilon \mathrm{Hf}(t)$ values of -20.43 to 9.54 (table S2).

Major and Trace Element Compositions. Major and trace element analytical results are presented in table S3. Given the low-grade alteration of the rock sequence and the likelihood for mobilization of elements with a large ionic radius to charge during low-grade metamorphism, the following discussion focuses on the so-called immobile elements and element ratios (Pearce and Cann 1978; Wood 1980; 

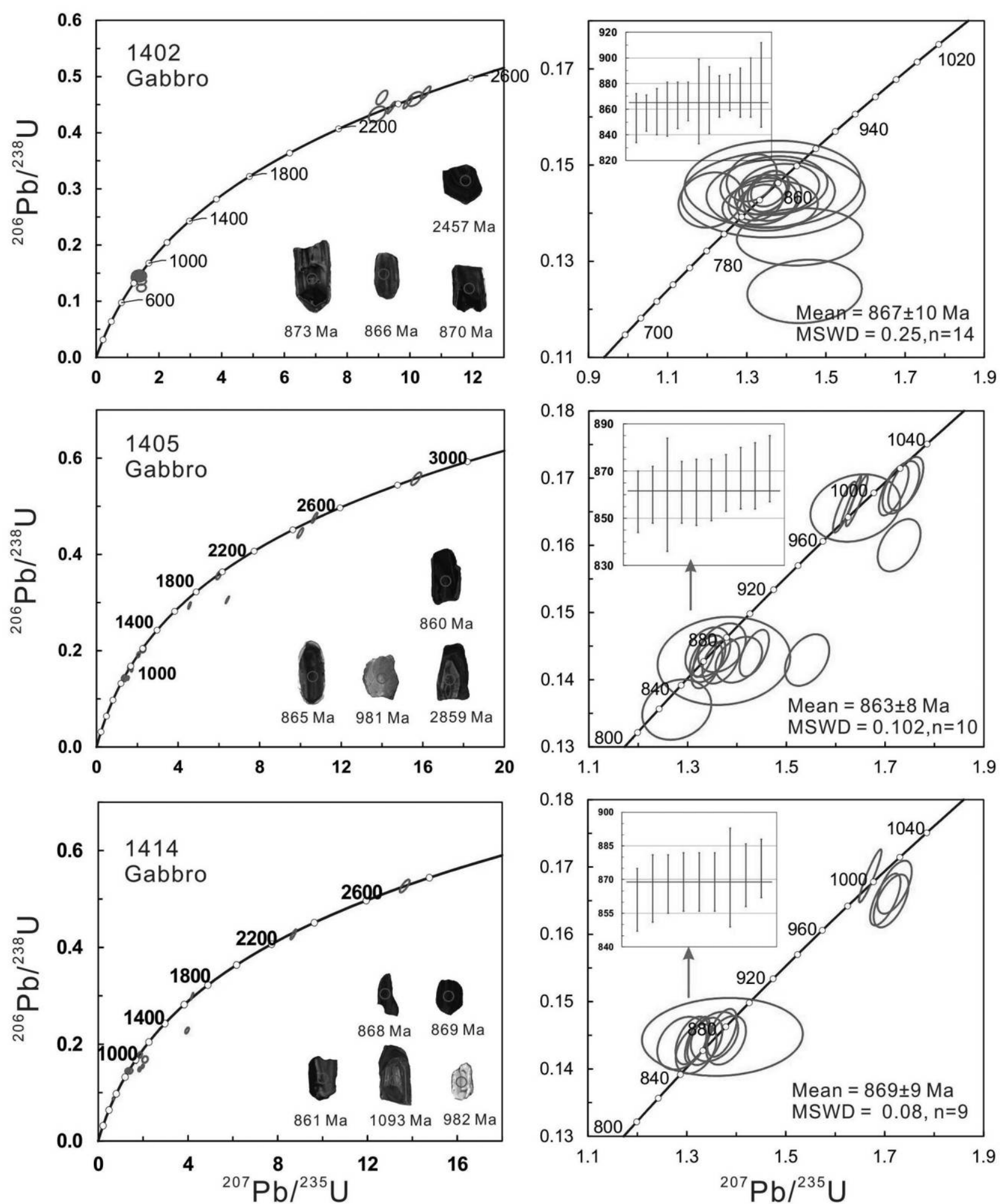

Figure 5. U-Pb concordia plots for zircons from gabbro from the Longsheng area in the western Jiangnan orogenic belt, South China Craton. A color version of this figure is available online. 

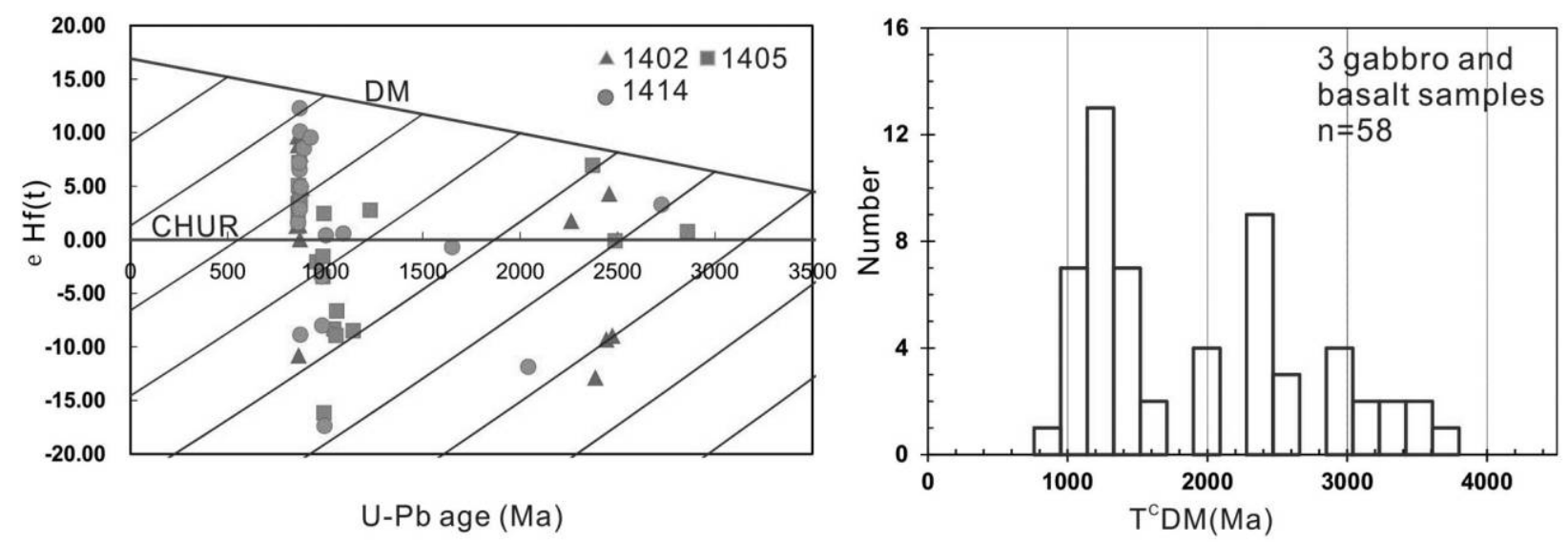

Figure 6. A, Plot of $\varepsilon \mathrm{Hf}(t)$ versus zircon $\mathrm{U}-\mathrm{Pb}$ ages for the gabbro. $B$, Histogram of zircon Hf model ages for the gabbro. $\mathrm{CHUR}=$ chondrite uniform reservoir; $\mathrm{DM}=$ depleted mantle. A color version of this figure is available online.

Wyman 1999). On the $\mathrm{Zr} / \mathrm{TiO}_{2}-\mathrm{Nb} / \mathrm{Y}$ diagram the samples fall in the basalt field (fig. 7). The gabbros and diabase have a wide compositional range for $\mathrm{TiO}_{2}(0.661 \%-1.742 \%), \mathrm{SiO}_{2}(47.2 \%-52.07 \%)$, and $\mathrm{Na}_{2} \mathrm{O}(0.64 \%-5.49 \%)$ and a high $\mathrm{Mg} \#$ of $47-51$ (table S3). The talc shows a compositional range of $60.99 \%-62.81 \%$ for $\mathrm{SiO}_{2}, 28.33 \%-30.36 \%$ for $\mathrm{MgO}$, $2.86 \%-5.01 \%$ for $\mathrm{FeO}^{\mathrm{t}}$, and $3.71 \%-5.72 \%$ for loss on ignition (table $\mathrm{S} 3$ ), whereas $\mathrm{Al}_{2} \mathrm{O}_{3}$ is largely depleted $(0 \%-0.07 \%)$. All gabbros and diabase display minor light rare earth element (LREE)-enriched patterns with $(\mathrm{La} / \mathrm{Yb})_{\mathrm{N}}$ ratios in the range of 2.8-17.9 and almost no Eu anomalies, with Eu/Eu* ratios of $~ 0.942-$ 0.75 (fig. 8). The serpentinite samples show features

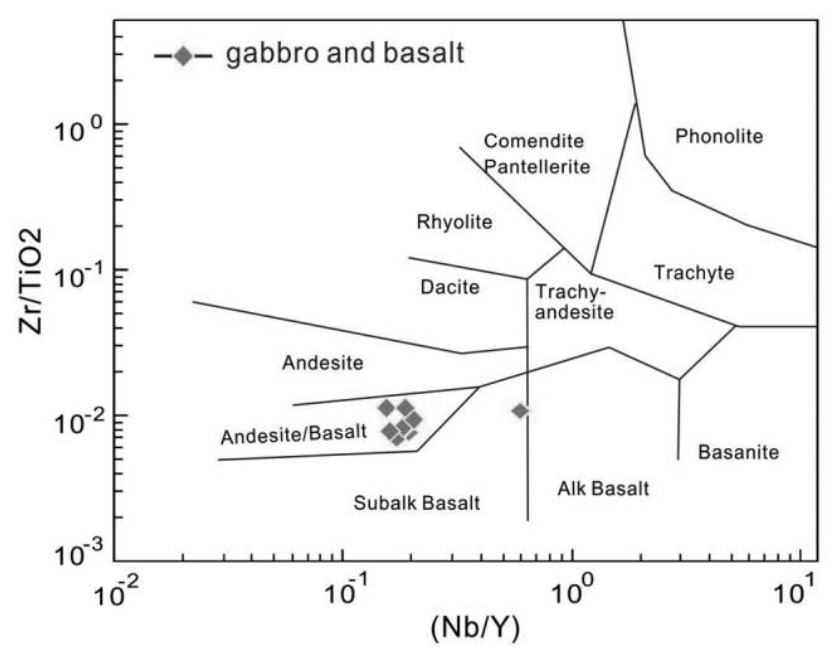

Figure 7. $\mathrm{Zr} / \mathrm{TiO}_{2}$ versus $\mathrm{Nb} / \mathrm{Y}$ diagram of analyzed mafic samples in this study. Alk = alkaline; Subalk = subalkaline. A color version of this figure is available online. similar to those of the gabbro (table S3). On primitive mantle-normalized plots the gabbros and diabases display enrichment in large ion lithophile elements such as $\mathrm{La}, \mathrm{Ce}, \mathrm{Cs}, \mathrm{Pb}$, and $\mathrm{Ba}$ and variable depletions in high field strength elements (HFSEs) such as $\mathrm{Nb}, \mathrm{Ta}, \mathrm{Pb}$, and $\mathrm{Hf}$ (fig. 8). Two talc samples from the northern mine (1305 and 1305-1) display LREE-enriched patterns with obvious Eu anomaly and depletion of $\mathrm{Rb}, \mathrm{Ba}, \mathrm{Nb}, \mathrm{Ta}, \mathrm{Pb}$, and $\mathrm{Cs}$ as well as enrichment in Th, $\mathrm{U}, \mathrm{La}, \mathrm{Ce}$, and Ti. The talc samples from the southern mine (1306 and 1306-1) display almost flat REE patterns with no $\mathrm{Ce}$ and $\mathrm{Eu}$ anomaly and depletion of $\mathrm{Rb}, \mathrm{Ba}$, and $\mathrm{Ti}$ as well as enrichment in Cs, Th, $\mathrm{U}, \mathrm{La}, \mathrm{Ce}$, and $\mathrm{Pb}$. The phyllite samples have $\mathrm{SiO}_{2}$ content of $67.59 \%-70.06 \%$, $\mathrm{CaO}$ content of $0.59 \%-1.04 \%, \mathrm{Na}_{2} \mathrm{O}$ content of $1.97 \%-4.10 \%$, and $\mathrm{K}_{2} \mathrm{O}$ content of $2.18 \%-3.05 \%$, with a $\mathrm{K}_{2} \mathrm{O} / \mathrm{Na}_{2} \mathrm{O}$ ratio of $0.5-1.5$ (table S3). The phyllite samples display LREE-enriched patterns, with depletion of $\mathrm{Eu}\left(\mathrm{Eu} / \mathrm{Eu}^{*}\right.$ ratios of $\left.\sim 0.72-0.79\right)$; depletion of $\mathrm{Ti}, \mathrm{Sr}, \mathrm{Nb}, \mathrm{Ta}$; and enrichment of $\mathrm{Th}$ also observed (fig. 8).

\section{Discussion}

Field Geology, Petrology, and Geochemistry. Neoproterozoic mafic-ultramafic rocks and marine sedimentary rocks are extensively exposed in the northern Guangxi area. The mafic-ultramafic suites at Longsheng are composed mainly of peridotite, pyroxenite, pillow basalt, diabase, and gabbro. Other lithologies include variably faulted ophicalcite, marble, jasper, and tuffaceous phyllite (figs. 3, 4). Mafic and ultramafic rocks along with marble, ophicalcite, and chert occur as isolated blocks within the sheared phyllite. Red jasper is found in the inter- 

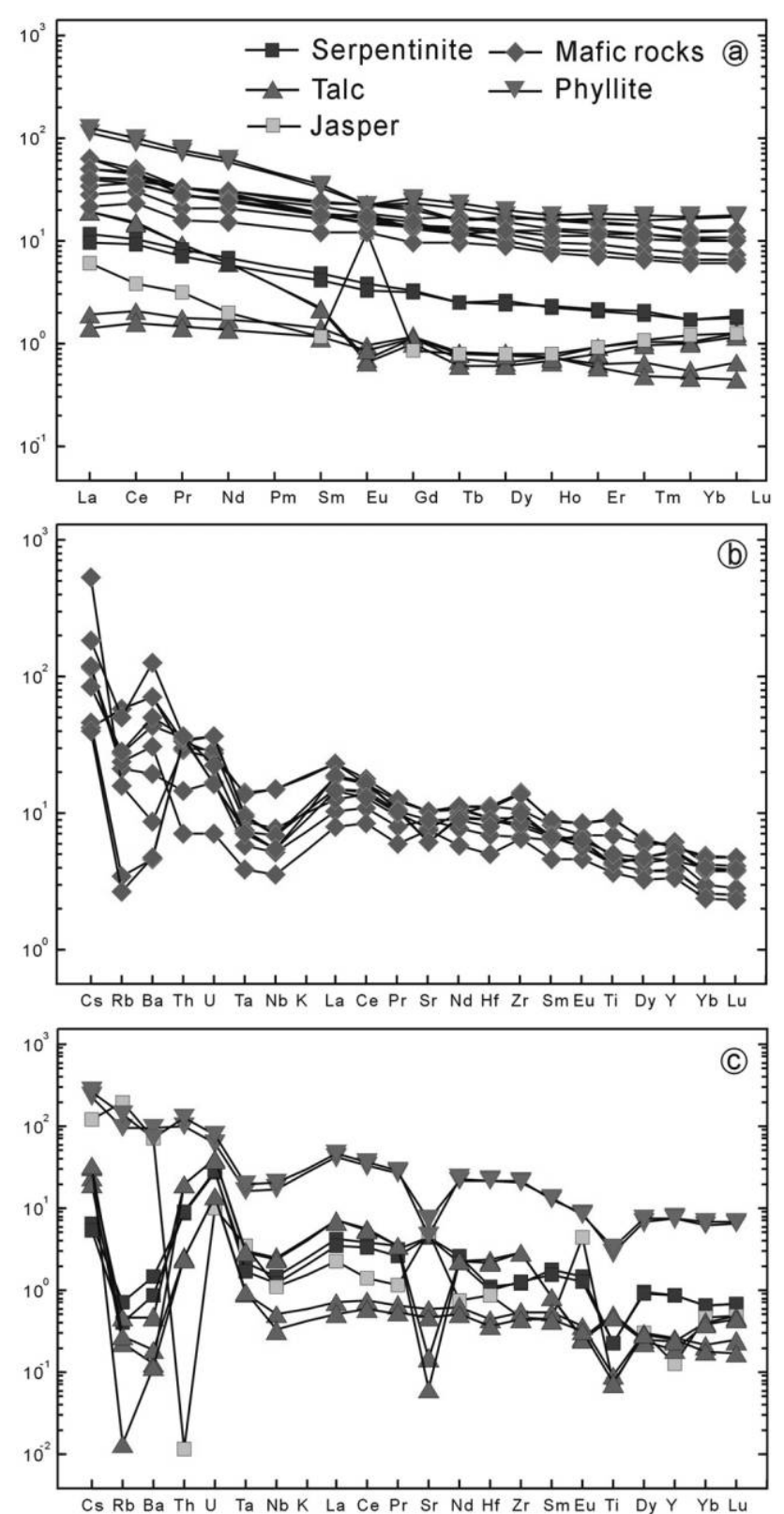

Figure 8. $a$, Chondrite-normalized rare earth element patterns for analyzed samples (normalization values are from Sun and McDonough 1989). b, Primitive mantlenormalized incompatible element distribution spidergrams for gabbro. $c$, Primitive mantle-normalized incompatible element distribution spidergrams for talc, phyllite, and serpentinite. The normalization values are from McDonough and Sun (1995). A color version of this figure is available online.

stices of the basalt and overlying carbonate (fig. 2a), which, together with the presence of pillow basalt and ophicalcite, suggests that some of the investigated blocks were formed in a deep marine environment isolated from terrestrial input (e.g., Grenne and Vokes 1990; Abdelsalam and Stern 1993). The peridotite and pyroxenite are generally serpentinized with greenschist to amphibolite facies metamorphism, and in the Longsheng area there are numerous talc exposures at contacts with siliceous marble and layered basalt as well as within the blocks of ultramafic rocks (Li 1979; BGMRGX 1985; fig. $2 b$ ).

Geochemical data, largely based on high field strength and transition elements, suggest formation in a convergent plate margin setting but with a few samples displaying MORB affinity. Most of the studied gabbro and diabase samples show a depletion in HFSEs such as $\mathrm{Nb}$, $\mathrm{Ta}$, and $\mathrm{Zr}$ compared with their neighboring elements (fig. 8), consistent with those of a typical volcanic arc setting (Wyman 1999). Tuffaceous phyllite also yields similar subductionrelated geochemical signatures. The gabbro and basalt samples from the Longsheng area display $\mathrm{TiO}_{2}$, $\mathrm{Ta}$, and $\mathrm{Nb}$ contents of $0.79 \%-1.75 \%, 10.14-0.52$ ppm $(<0.7 \mathrm{ppm})$, and 2.34-9.91 ppm ( $\leq 12 \mathrm{ppm})$, respectively. Furthermore, these rocks show $\mathrm{Nb} / \mathrm{La}$ ratios of $0.3-0.67(\leq 1), \mathrm{Hf} / \mathrm{Ta}$ ratios of 5.02-9.94 (>5), $\mathrm{La} / \mathrm{Ta}$ ratios of $25.9-43.8(>15), \mathrm{Hf} / \mathrm{Th}$ ratios of $\sim 0.78-$ $2.55(<8), \mathrm{Th} / \mathrm{Yb}$ ratios of $0.54-2.34(>0.1), \mathrm{Th} / \mathrm{Nb}$ ratios of $0.23-0.8(>0.07)$, and $\mathrm{Nb} / \mathrm{La}$ ratios of $0.3-$ $0.37(<0.8$; table S3), similar to those of arc basalts, and plot in the field of arc basalts (fig. 9; Condie 1989). A few gabbros plot in the MORB field on some tectonic discrimination diagrams, with REE patterns similar to those of enriched MORB. Representative talc samples from the studied region show very low trace element content and varied patterns. Those from the northern mine (1305 and 1305-1), which lie in the contact zone of marble and basalt, display an LREE-enriched pattern with depletion in $\mathrm{Rb}, \mathrm{Ba}, \mathrm{Nb}, \mathrm{Ta}, \mathrm{Sr}$, and $\mathrm{Pb}$ and enrichment in Ti that are of arc affinity (figs. 8, 9). Those from the southern mine (1306 and 1306-1) display an almost flat REE pattern, with enrichment in $\mathrm{Cs}$ and $\mathrm{Pb}$ and depletion in $\mathrm{Rb}, \mathrm{Ba}$, and $\mathrm{Ti}$. No $\mathrm{Nb}$ and $\mathrm{Ta}$ were observed. On the basis of field contacts and mineral assemblages within talc samples, we believe these geochemical features suggest that there are two types of talc mine in the Longsheng area. The northern mine was generated by metasomatism of marble and arc-type basalt, which produce purer talc, whereas in the southern mine the talc occurs within ultramafic rock of MORB affinity.

In summary, although the contacts between the igneous and sedimentary rock units (peridotite, pyroxenite, gabbro, basalt mixed with siliceous marble and jasper, and ophicalcite) are generally structural within a matrix of sandy and tuffaceous phyllite and parts of the mafic-ultramafic assemblage are 

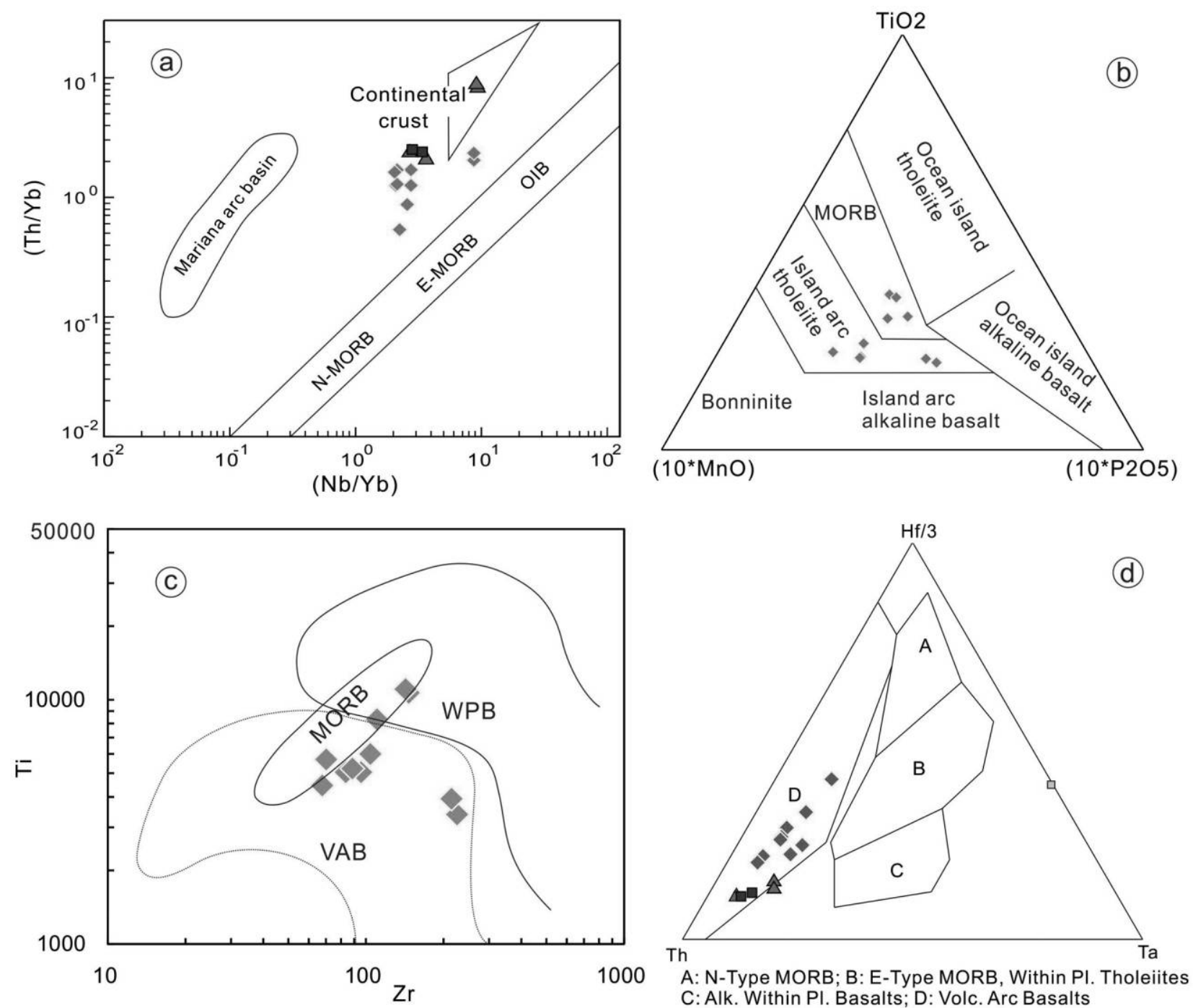

Figure 9. $a, \mathrm{Th} / \mathrm{Yb}$ versus $\mathrm{Nb} / \mathrm{Yb}$ discrimination diagram for intermediate-mafic igneous suite (after Pearce 2008). $b, \mathrm{TiO}_{2}-10^{*} \mathrm{MnO}-10^{*} \mathrm{P}_{2} \mathrm{O}_{5}$ discriminant diagrams for gabbro samples (after Mullen 1983). c, Plot of Ti-Zr for gabbro samples (after Pearce and Cann 1973). d, Th-Hf-Ta diagram (after Wood 1980) for the samples from the Longsheng area, western Jiangnan orogenic belt. E-MORB = enriched MORB; MORB = mid-ocean ridge basalt; N-MORB = normal $\mathrm{MORB} ; \mathrm{OIB}=$ ocean island basalt; $\mathrm{VAB}=$ volcanic arc basalt; $\mathrm{WPB}=$ within-plate basalt. A color version of this figure is available online.

strongly altered (serpentinite and talc), the overall lithological assemblage, together with a magmatic arc and reported MORB geochemical fingerprints, is consistent with a disrupted ophiolitic mélange from a forearc environment.

Tectonic Implications. Any tectonic model for the Jiangnan orogenic belt must account for the following: (1) its position at the boundary zone between the accreted Cathaysia and Yangtze blocks, (2) a lithologic assemblage within the belt dominated by mafic igneous rocks and related units ranging in age from ca. 990 to $860 \mathrm{Ma}$ in the eastern segment (Gao et al. 2009; Li et al. 2009; Shu 2012;
Yao et al. 2013, 2016) and from 860 to $830 \mathrm{Ma}$ in the central and western segments (Chen et al. 2014; Yao et al. 2014; Zhang and Wang 2016), and (3) a consistent convergent plate margin geochemical signature throughout this time frame (Zhao and Cawood 2012; Cawood et al. 2013; Yao et al. 2015). On this basis the Jiangnan orogenic belt is considered part of an accretionary orogen (cf. Cawood et al. 2009) postdating Rodinia assembly and located on its northern margin (Cawood et al. 2013). We believe these age and geochemical relationships argue against models suggesting an internal setting within an assembled Rodinia (e.g., Li et al. 2008). 
Features of the Jiangnan belt in the Longsheng area-including the presence of blocks of a maficultramafic assemblage of both arc and MORB affinity within a phyllitic matrix, basalt overlain by carbonate, and red jasper, along with blocks of varied sedimentary units-enable refinement of the SSZ setting. In particular, the extensive disruption of the succession in which the more rheologically competent units are sheared into discontinuous blocks in a phyllitic matrix and the entire succession is imbricated along east-directed thrusts suggests that the Longsheng area constitutes a tectonic mélange within an accretionary prism (e.g., Cawood 1984; Wakabayashi and Dilek 2003). Furthermore, the greenschist to amphibolite facies metamorphism of mafic-ultramafic units, which is of higher grade than that of phyllitic matrix, indicates a possible seafloor metamorphism of mafic-ultramafic units prior to being incorporated into the tectonic complex. Kinematic analysis in the eastern Jiangnan belt has noted a similar pattern, with ductile southeastwarddirected thrusts in an overall northwest-dipping succession, and is related to northwestward subduction of oceanic lithosphere beneath the southeast Yangtze block (Shu et al. 1994; Charvet et al. 1996; Shu and Charvet 1996).

$\mathrm{U}-\mathrm{Pb}$ dating of the gabbroic rocks within the Sibao Group in the Longsheng area yields ages in the range of $870-860 \mathrm{Ma}$ (fig. 5), coeval with ages constrained by detrital zircon U-Pb dating for the Sibao
Group (Zhou et al. 2014). Mafic-ultramafic and intermediate suites in the Yuanbaoshan and Sanfang regions, west of Longsheng, which include gabbro, pillow basalt, and high-Mg andesite, are dated at ca. 855-830 $\mathrm{Ma}$ and are related to a convergent plate margin (Zhou et al. 2004; Zhao and Zhou 2013; Chen et al. 2014; Yao et al. 2014). Field relations, rock suites, ages, and geochemical signatures throughout the Jiangnan belt argue against models suggesting an extensional setting for these maficultramafic units (Li et al. 1999; Ge et al. 2001). S-type granites intrude the Sibao Group but are more common to the west of the study area at Yuanbaoshan and Sanfang, where they have yielded ages of 830$820 \mathrm{Ma}$ (zircon U-Pb dating; Li et al. 2003; Yao et al. 2014). Field relations suggest that the granites intruded into predeformed phyllite and mafic-ultramafic and intermediate suites of the Sibao Group (Ge et al. 2001; Chen et al. 2014; Yao et al. 2014). Elsewhere within the orogen, S-type granites yield ages in the range of $830-800 \mathrm{Ma}$ and contain inherited early Neoproterozoic and Mesoproterozoic grains, suggesting anatexis of older basement lithologies, likely representative of the Yangtze block (e.g., Li et al. 2003; Yao et al. 2014). These granitic intrusions have been related to collisional assembly of the Yangtze and Cathaysia blocks (Shu 2012; Yao et al. 2014).

Figure 10 presents a schematic tectonic model for the formation of the disrupted ophiolitic mélange in the Longsheng area of the western Jiangnan oro-

\section{West Jiangnan arc ca. 830-870 Ma}

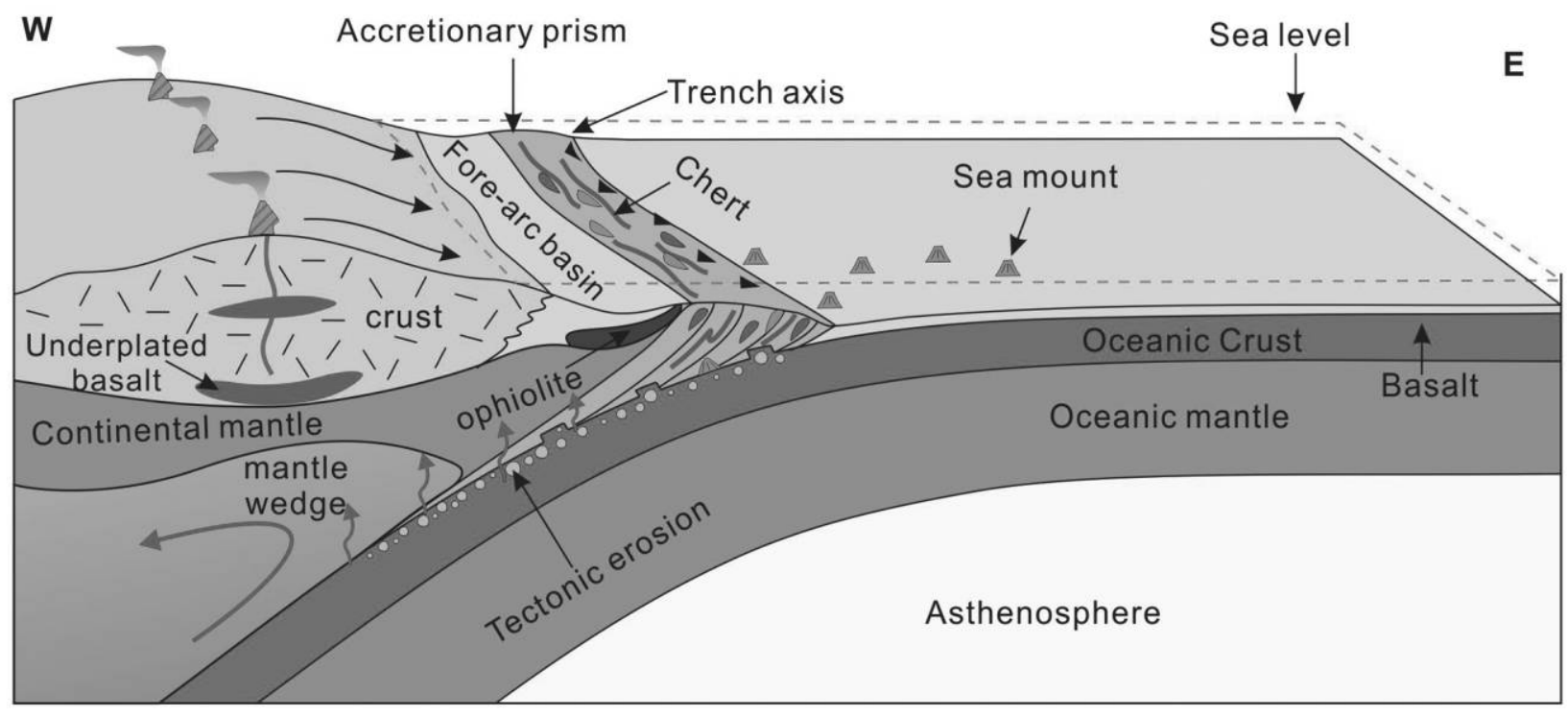

Figure 10. Tectonic evolution model for the western Jiangnan orogenic belt, South China. A color version of this figure is available online. 
genic belt within an accretionary prism environment. The trench is inferred to lie to the east, consistent with the orientation and kinematics of the observed thrust faults, as well as the previously constrained subduction direction (Shu and Charvet 1996), while the magmatic arc to the accretionary complex is inferred to lie to the west, consistent with geochemical studies of volcanic arc successions in this and adjacent regions (Chen et al. 2014; Yao et al. 2014). The presence of chert, carbonate, and tuffaceous phyllite suggests that the sedimentary units include sea-floor- and arc-derived volcanogenic successions. The geochemistry of the maficultramafic blocks, which predominantly include the SSZ along with some of the MORB affinities, suggests incorporation of parts of the magmatic arc (or arc basement) as well as off-scrapped sea floor. The overall structure and lithology resembles a forearc ophiolitic mélange (Gansser 1974; Williams 1977). Within this ophiolitic mélange, the arc components are autochthonous blocks, whereas igneous blocks of MORB ones and chert are exotic and derived from the subducting plate. The higher metamorphic grade of the mafic-ultramafic blocks relative to the matrix lithologies suggests possible sea-floor metamorphism of the blocks prior to incorporation into the accretionary prism or that they were subducted to a deeper depth before exhumation and incorporation into the mélange. The intermediate volcanic rocks and granodiorite with arc geochemistry reported by Xia (1984) and BGMRGX (1985) from the Longsheng region coincide well with the tectonic model. The inherited Proterozoic xenocrystic zircons in the analyzed gabbros of arc affinity (fig. 5) are related to incorporation of continental sediments and suggest the presence of a possible continental arc.

The concordia age of ca. $865 \mathrm{Ma}$ reported in this study constrains the time of inferred ophiolitic mélange. The ca. $765 \mathrm{Ma}$ age reported for intrusive metadacite in the Longsheng region (Zhou et al. 2007) likely represents the effects of subsequent rifting tectonothermal activity related to the breakup of Rodinia, which is widespread in South China (Zhao and Cawood 2012 and references therein). Backarc SSZ-type ophiolite suites as well as forearc MORB type are also exposed in the east
Jiangnan belt and dated at 900-1000 Ma (Shu 2012; Wang et al. 2015). Ages of ophiolitic components throughout the Jiangnan belt coincide with the younging direction of arc and basement sequences toward the western segment (Wang et al. 2014). Ridge subduction-related ophiolite inferred from geochemical data has also been proposed from the eastern Jiangnan belt (Zhang et al. 2015). However, without clear lithostratigraphic field data indicating that magmatic activity is emplaced into a recently formed and unequivocal accretionary prism, a ridge subduction model is difficult to justify. A convergent plate margin setting for the western Jiangnan belt at $860 \mathrm{Ma}$ also argues against ca. 900$880 \mathrm{Ma}$ collision and ca. $860 \mathrm{Ma}$ rifting of the western Jiangnan belt as well as the entire South China Craton (e.g., Ge et al. 2001; Li et al. 2008).

\section{Conclusion}

The disrupted and pervasively sheared association of mafic-ultramafic igneous rocks, together with chert, siliceous marble, ophicalcite, and phyllite, in the Longsheng area of the Jiangnan orogenic belt, South China, is interpreted as an imbricated forearc ophiolitic mélange. U-Pb zircon data indicate an age of ca. $865 \mathrm{Ma}$ for the gabbros and diabases of the assemblage, and geochemical data constrain the setting to an SSZ environment. The disruption and thrust imbrication of the sequence is related to a subduction complex.

\section{A C KN O W LED G M EN TS}

Reviews by two anonymous reviewers and D. Rowley are gratefully acknowledged for their constructive comments and suggestions that led to a major improvement of the manuscript. We also express our gratitude to J. Q. Wang and Y. H. Yang for their help during zircon dating and Hf isotopic study. We acknowledge the financial support provided by the National Basic Research Program of China 1973 Program, 2012CB416701) and the National Natural Science Foundation of China (41330208 and 41572200).

\section{REFERENCES CITED}

Abdelsalam, M. G., and Stern, R. J. 1993. Tectonic evolution of the Nakasib suture, Red Sea Hills, Sudan: evidence for a late Precambrian Wilson cycle. L. Geol. Soc. Lond. 1150:393-404.
BGMRGX (Bureau of Geology and Mineral Resources of Guangxi Province). 1985. Regional geology of Guangxi autonomous region. Beijing, Geological Publishing House, 853 p. (in Chinese with English abstract). 
Blichert-Toft, J., and Albarede, F. 1997. The Lu-Hf isotope geochemistry of chondrites and the evolution of the mantle-crust system. Earth Planet. Sci. Lett. 148: 243-258.

Cawood, P. A. 1984. A geochemical study of metabasalts from a subduction complex in eastern Australia. Chem. Geol. 43:29-47.

Cawood, P. A.; Kroner, A.; Collins, W. J.; Kusky, T. M.; Mooney, W. D.; and Windley, B. F. 2009. Accretionary orogens through Earth history. Geol. Soc. Lond. Spec. Publ. 318:1-36.

Cawood, P. A.; Wang, Y. J.; Xu, Y. J.; and Zhao, G. C. 2013. Locating South China in Rodinia and Gondwana: a fragment of Greater Indian Lithosphere? Geology 41(8):903-906.

Charvet, J.; Shu, L. S.; Shi, Y. S.; Guo, L. Z.; and Faure, M. 1996. The building of South China: collision of Yangtze and Cathaysia blocks, problems and tentative answers. I. Asian Earth Sci. 13:223-235.

Chen, X.; Rowley, D. B.; Rong, J.; Zhang, J.; Zhang, Y.-D.; and Zhan, R.-B. 1997. Late Precambrian through early Paleozoic stratigraphic and tectonic evolution of the Nanling region, Hunan province, South China. Int. Geol. Rev. 39:469-478.

Chen, X.; Wang, D.; Wang, X. L.; Gao, J. F.; Shu, X. J.; Zhou, J. C.; and Qi, L. 2014. Neoproterozoic chromitebearing high-Mg diorites in the western part of the Jiangnan orogen, southern China: geochemistry, petrogenesis and tectonic implications. Lithos 200-201: 35-48.

Condie, K. C. 1989. Geochemical changes in basalts and andesites across the Archean-Proterozoic boundary: identification and significance. Lithos 23:1-18.

Gansser, A. 1974. The ophiolitic mélange, a world-wide problem on Tethyan examples. Eclogae Geol. Helv. 67: 479-507.

Gao, J.; Klemd, R.; Long, L. L.; Xiong, X. M.; and Qian, Q. 2009. Adakitic signature formed by fractional crystallization: an interpretation for the Neoproterozoic meta-plagiogranites of the NE Jiangxi ophiolitic mélange belt, South China. Lithos 110:277-293.

Ge, W. C.; Li, X. H.; Liang, X. R.; Wang, R. C.; Li, Z. X.; and Zhou, H. W. 2001. Geochemical and geological implications of mafic-ultramafic rocks with age of $\sim 825 \mathrm{Ma}$ in Yuanbaoshan-Baotan area of northern Guangxi. Geochimica 30:123-130 (in Chinese with English abstract).

Grenne, T., and Vokes, F. M. 1990. Sea-floor sulfides at the Høydal volcanogenic deposit, central Norwegian Caledonides. Econ. Geol. 85:344-359.

Li, X. H.; Li, W. X.; Li, Z. X.; Lo, C. H.; Wang, J.; Ye, M. F.; and Yang, Y. H. 2009. Amalgamation between the Yangtze and Cathaysia blocks in South China: constraints from SHRIMP U-Pb zircon ages, geochemistry and Nd-Hf isotopes of the Shuangxiwu volcanic rocks. Precambrian Res. 174:117-128.

Li, X. H.; Li, Z. X.; Ge, W.; Zhou, H.; Li, W.; Liu, Y.; and Wingate, M. T. D. 2003. Neoproterozoic granitoids in
South China: crustal melting above a mantle plume at ca. $825 \mathrm{Ma}$ ? Precambrian Res. 122:45-83.

Li, X. H.; Zhao, J. X.; McCulloch, M. T.; Zhou, G. Q.; and Xing, F. M. 1997. Geochemical and Sm-Nd isotopic study of Neoproterozoic ophiolites from southeastern China: petrogenesis and tectonic implications. Precambrian Res. 81:129-144.

Li, Y. Y. 1979. Discussion on the genesis of Longsheng talc mine. Non-Met. Mines 1:16-20.

Li, Z. X.; Bogdanova, S. V.; Collins, A. S.; Davidson, A.; De Waele, B.; Ernst, R. E.; Fitzsimons, I. C. W.; et al. 2008. Assembly, configuration, and break-up history of Rodinia: a synthesis. Precambrian Res. 160:179-210.

Li, Z. X.; Li, X. H.; Kinny, P. D.; and Wang, J. 1999. The breakup of Rodinia: did it start with a mantle plume beneath South China? Earth Planet. Sci. Lett. 173: 171-181.

Ludwig, K. R. 2003. Isoplot 3.00, a geochronological toolkit for Microsoft Excel. Berkeley Geochronol. Cent. Spec. Publ. 4:1-70.

McDonough, W. F., and Sun, S. S. 1995. Composition of the Earth. Chem. Geol. 120:223-253.

Mullen, E. D. 1983 . $\mathrm{MnO} / \mathrm{TiO}_{2} / \mathrm{P}_{2} \mathrm{O}_{5}$ : a minor element discriminant for basaltic rocks of oceanic environments and its implications for petrogenesis. Earth Planet. Sci. Lett. 62:53-62.

Pearce, J. A. 2003. Supra-subduction zone ophiolites: the search for modern analogues. In Dilek, Y., and Newcomb, S., eds. Ophiolite concept and the evolution of geological thought. Geol. Soc. Am. Spec. Pap. 373: 269-293.

. 2008. Geochemical fingerprinting of oceanic basalts with applications to ophiolite classification and the search for Archean oceanic crust. Lithos 100:14-48.

Pearce, J. A., and Cann, J. R. 1973. Tectonic setting of basic volcanic rocks determined using trace element analysis. Earth Planet. Sci. Lett. 19:290-300.

Scherer, E.; Munker, C.; and Mezger, K. 2001. Calibration of the lutetium-hafnium clock. Science 293:683-687.

Shu, L. S. 2012. An analysis of principal features of tectonic evolution in South China block. Geol. Bull. China 31:1035-1053.

Shu, L. S., and Charvet, J. 1996. Kinematics and geochronology of the Proterozoic Dongxiang-Shexian ductile shear zone: with HP metamorphism and ophiolitic melange (Jiangnan region, South China). Tectonophysics 267:291-302.

Shu, L. S.; Zhou, G. Q.; Shi, Y. S.; and Yin, J. 1994. Study on the high pressure metamorphic blueschist and its late Proterozoic age in the eastern Jiangnan belt. Chinese Sci. Bull. 39:1200-1204.

Stern, R. J.; Reagan, M.; Ishizuka, O.; Ohara, Y.; and Whattam, S. 2012. To understand subduction initiation, study forearc crust: to understand forearc crust, study ophiolites. Lithosphere 4:469-483.

Sun, C. Y., and Vuagnat, V. 1992. Proterozoic ophiolites from Yanbian and Shimian (Sichuan province, China): petrography, geochemistry, petrogenesis, and geotec- 
tonic environment. Schweiz. Mineral. Petrogr. Mitt. 72:389-413.

Sun, S. S., and McDonough, W. F. 1989. Chemical and isotopic systematics of oceanic basalts: implication for mantle composition and processes. In Saunder, A. D., and Norry, M. J., eds. Magmatism in the ocean basins. Geol. Soc. Lond. Spec. Publ. 42:313-345.

Wakabayashi, J., and Dilek, Y. 2003. What constitutes "emplacement" of an ophiolite? mechanisms and relationship to subduction initiation and formation of metamorphic soles. In Dilek, Y., and Robinson, P. T., eds. Ophiolites in Earth history. Geol. Soc. Lond. Spec. Publ. 218:427-448.

Wang, J., and Li, Z. X. 2003. History of Neoproterozoic rift basins in South China: implications for Rodinia break-up. Precambrian Res. 122:141-158.

Wang, X. L.; Zhou, J. C.; Griffin, W. L.; Zhao, G. C.; Yu, J. H.; Qiu, J. S.; Zhang, Y. J.; and Xing, G. F. 2014. Geochemical zonation across a Neoproterozoic orogenic belt: isotopic evidence from granitoids and metasedimentary rocks of the Jiangnan orogen, China. Precambrian Res. 242:154-171.

Wang, X. S.; Gao, J.; Klemd, R.; Jiang, T.; Zhai, Q. G.; Xiao, X. C.; and Liang, X. Q. 2015. Early Neoproterozoic multiple arc-back-arc system formation during subduction-accretion processes between the Yangtze and Cathaysia blocks: new constraints from the suprasubduction zone NE Jiangxi ophiolite (South China). Lithos 236-237:90-105.

Wang, Y. J.; Zhang, A. M.; Cawood, P. A.; Fan, W. M.; Xu, J. F.; Zhang, G. W.; and Zhang, Y. Z. 2013. Geochronological, geochemical and Nd-Hf-Os isotopic fingerprinting of an early Neoproterozoic arc-back-arc system in South China and its accretionary assembly along the margin of Rodinia. Precambrian Res. 231:343-371.

Williams, H. 1977. Ophiolitic mélange and its significance in the Fleur de Lys Supergroup, northern Appalachians. Can. I. Earth Sci. 14:987-1003.

Wood, D. A. 1980. The application of a Th-Hf-Ta diagram to problems of tecto-magmatic classification and to establishing the nature of crustal contamination of basaltic lavas of the British Tertiary volcanic province. Earth Planet. Sci. Lett. 50:11-30.

Wyman, D. A. 1999. A 2.7 Ga depleted tholeiite suite: evidence of plume-arc interaction in the Abitibi Greenstone belt, Canada. Precambrian Res. 97:27-42.

Xia, B. 1984. A study on geochemical characteristic and emplaced style of two different ophiolite of late Proterozoic Xuefeng stage in the Longsheng region, Guangxi, South China. J. Nanjing Univ. Nat. Sci. 3: 554-566 (in Chinese with English abstract).
Yao, J. L.; Shu, L. S.; Cawood, P. A.; and Li, J. Y. 2016. Delineating and characterizing the boundary of the Cathaysia block and the Jiangnan orogenic belt in South China. Precambrian Res. 275:265-277.

Yao, J. L.; Shu, L. S.; Santosh, M.; and Li, J. Y. 2013. Geochronology and $\mathrm{Hf}$ isotope of detrital zircons from Precambrian sequences in the eastern Jiangnan orogen: constraining the assembly of Yangtze and Cathaysia blocks in South China. I. Asian Earth Sci. 74:225-243.

- 2015. Neoproterozoic arc-related andesite and orogeny-related unconformity in the eastern Jiangnan orogenic belt: constraints on the assembly of the Yangtze and Cathaysia blocks in South China. Precambrian Res. 262:84-100.

Yao, J. L.; Shu, L. S.; Santosh, M.; and Zhao, G. C. 2014. Neoproterozoic arc-related mafic-ultramafic rocks and syn-collision granite from the western segment of the Jiangnan orogen, South China: constraints on the Neoproterozoic assembly of the Yangtze and Cathaysia blocks. Precambrian Res. 243:39-62.

Zhang, C. L.; Zou, H. B.; Zhu, Q. B.; and Chen, X. Y. 2015. Late Mesoproterozoic to early Neoproterozoic ridge subduction along southern margin of the Jiangnan orogen: new evidence from the northeastern Jiangxi ophiolite (NJO), South China. Precambrian Res. 268: $1-15$.

Zhang, Y. Z., and Wang, Y. J. 2016. Early Neoproterozoic ( $840 \mathrm{Ma})$ arc magmatism: geochronological and geochemical constraints on the metabasites in the central Jiangnan orogen. Precambrian Res. 275:1-17.

Zhao, G. C. 2015. Jiangnan orogen in South China: developing from divergent double subduction. Gondwana Res. 27:1173-1180.

Zhao, G. C., and Cawood, P. A. 2012. Precambrian geology of China. Precambrian Res. 222-223:13-54.

Zhao, J. H., and Zhou, M. F. 2013. Neoproterozoic high$\mathrm{Mg}$ basalts formed by melting of ambient mantle in South China. Precambrian Res. 233:193-205.

Zhou, J. B.; Li, X. H.; Ge, W. C.; and Li, Z. X. 2007. Age and origin of middle Neoproterozoic mafic magmatism in southern Yangtze block and relevance to the break-up of Rodinia. Gondwana Res. 12:184-197.

Zhou, J. C.; Wang, X. L.; and Qiu, J. S. 2014. Neoproterozoic tectono-magmatic evolution of the Jiangnan orogen. Beijing, Science Press, 282 p. (in Chinese with English abstract).

Zhou, J. C.; Wang, X. L.; Qiu, J. S.; and Gao, J. F. 2004. Geochemistry of Meso- and Neoproterozoic maficultramafic rocks from northern Guangxi, China: arc or plume magmatism? Geochem. I. 38:139-152. 